\title{
36. OXIDATION STATE AND SULFUR CONCENTRATIONS IN LAU BASIN BASALTS ${ }^{1}$
}

\author{
Kristen Nilsson Farley²
}

\begin{abstract}
The backarc glasses recovered during Ocean Drilling Program Leg 135 are unique among submarine tholeiitic glasses with respect to their oxygen fugacity and sulfur concentrations. Unlike mid-ocean-ridge basalt glasses, $f \mathrm{O}_{2}$ in these samples (inferred from ratios $\left.\mathrm{Fe}^{3+} / \mathrm{Fe}^{2+}\right)$ is high and variable, and $\mathrm{S}$ variations $(90-1140 \mathrm{ppm}$ ) are not coupled with $\mathrm{FeO}$ concentration. Strong correlations occur between the alkali and alkaline-earth elements and both $f \mathrm{O}_{2}$ (positive correlations) and S concentrations (negative correlations). Correlations between $f \mathrm{O}_{2}$ and various trace elements are strongest for those elements with a known affinity for hydrous fluids (perhaps produced during slab dehydration), suggesting the presence of a hydrous fluid with high $f \mathrm{O}_{2}$ and high alkali and alkaline earth element concentrations in the Lau Basin mantle.

Concentrations of $\mathrm{S}$ and $f \mathrm{O}_{2}$ are strongly correlated; high $\mathrm{fO}_{2}$ samples are characterized by low $\mathrm{S}$ in addition to high alkali and alkaline earth element concentrations. The negative correlations between $\mathrm{S}$ and these trace elements are not consistent with incompatible behavior of S during crystallization. Mass balance considerations indicate that the $\mathrm{S}$ concentrations cannot result simply from mixing between low-S and high-S sources. Furthermore, there is no relationship between $\mathrm{S}$ and other trace elements or isotope ratios that might indicate that the $\mathrm{S}$ variations reflect mixing processes. The $\mathrm{S}$ variations more likely reflect the fact that when silicate coexists with an $\mathrm{S}$-rich vapor phase the solubility of $\mathrm{S}$ in the silicate melt is a function of $f \mathrm{O}_{2}$ and is at a minimum at the $f \mathrm{O}_{2}$ conditions recorded by these glasses. The absence of Fe-sulfides and the high and variable vesicle contents are consistent with the idea that $\mathrm{S}$ concentrations reflect silicate-vapor equilibria rather than silicate-sulfide equilibria (as in MORB). The low S contents of some samples, therefore, reflect the high $f \mathrm{O}_{2}$ of the supra-subduction zone environment rather than a low-S source component.
\end{abstract}

\section{INTRODUCTION}

Numerous studies have demonstrated that backarc basin basalts (BABB) span a compositional range between mid-ocean-ridge basalts (MORB) and island arc volcanics (IAV) (e.g., Hawkins and Melchior, 1985; Perfit et al., 1987; Sinton and Fryer, 1987; Volpe et al., 1987, 1988; Fryer et al., 1990; Hawkins et al., 1990). The oxygen fugacity $\left(f \mathrm{O}_{2}\right)$ of backarc magmas has never been systematically investigated, although it has been suggested to be higher than that of MORB (Hawkins and Melchior, 1985; Sinton and Fryer, 1987; Hochstaedter, Gill, Kusakabe, et al., 1990). This would have several important implications. The behavior of elements with multiple valence states and the solubility of volatile species are strongly affected by $f \mathrm{O}_{2}$. For example, variations in the $\mathrm{Fe}^{3+} / \mathrm{Fe}^{2+}$ ratio influence the extent and timing of oxide fractionation and the composition of residual magmas. Furthermore, $f \mathrm{~S}_{2}$ and $\mathrm{S}$ solubility are intimately related to $f \mathrm{O}_{2}$ and thus $f \mathrm{O}_{2}$ exerts a strong control on the behavior of $\mathrm{S}$.

This chapter presents $f \mathrm{O}_{2}$ and $\mathrm{S}$ concentrations of BABB glass recovered in the Lau Basin during Ocean Drilling Program (ODP) Leg 135 (Fig. 1) so as to constrain the relationship between the two parameters in a wide variety of BABB compositions. The Leg 135 backarc samples are an ideal sample set because a large number of chemically distinct units with adequate amounts of fresh glass were recovered (Parson, Hawkins, Allan, et al., 1992). Fresh glass is critical for $f \mathrm{O}_{2}$ and $\mathrm{S}$ analyses because syn- and post-eruptive degassing and alteration reactions can render even fresh crystalline material unsuitable (e.g., Sato, 1978; Mathez, 1984; Christie et al., 1986).

To address questions concerning the $\mathrm{fO}_{2}$ and $\mathrm{S}$ contents of the IAV source properly, a comprehensive study of pristine, undegassed arc glasses would be desirable. Because such material is extremely rare,

\footnotetext{
${ }^{1}$ Hawkins, J., Parson, L., Allan, J., et al., 1994. Proc. ODP, Sci. Results, 135: College Station, TX (Ocean Drilling Program).

${ }^{2}$ Scripps Institution of Oceanography, University of California, San Diego, La Jolla, CA 92093-0208, U.S.A. (present address: Department of Geology, Whittier College, Whittier, CA 90608).
}

$\mathrm{BABB}$ become a particularly valuable proxy. Numerous isotopic and trace element studies have concluded that BABB magmas contain an arc-like component (e.g., Hawkins and Melchior, 1985; Sinton and Fryer, 1987; Volpe et al., 1987, 1988; Hawkins et al., 1990; Hergt and Hawkesworth, this volume); however, unlike IAV, BABB are not extensively degassed and glassy material is abundant. In addition, $\mathrm{BABB}$ are typically less fractionated than arc lavas; the more $\mathrm{Mg}$-rich samples are more likely to reflect the source signature than the effects of crystallization. By studying BABB glasses, we can attempt to place some constraints on the $\mathrm{S}$ and $f \mathrm{O}_{2}$ characteristics of the arc-like end-member in $\mathrm{BABB}$ petrogenesis and perhaps on the IAV source as well.

The island arc volcanics, and some BABB, are enriched in certain trace elements that are thought to be derived from a hydrous fluid (or possibly melt) produced during dehydration of the downgoing slab (e.g., Perfit et al., 1980; Gill, 1981; Hawkins and Melchior, 1985; Hochstaedter, Gill, and Morris, 1990; McCullogh and Gamble, 1991; Hawkesworth et al., 1991). One goal of this work is to compare the $\mathrm{fO}_{2}$ and $\mathrm{S}$ characteristics of the Leg 135 backarc samples to MORB (about which we know a great deal) and IAV (about which we know very little). Those samples that suggest significant deviations from MORB-like compositions may reflect the incorporation of this hydrous fluid in their $f \mathrm{O}_{2}$ and $\mathrm{S}$ signatures.

\section{METHODS}

Major element and $\mathrm{S}$ concentrations were determined by electron microprobe on 73 glasses from the Leg 135 backarc sites. Many of these glasses were also analyzed for trace elements and radiogenic isotopes by Hergt and Hawkesworth (this volume). Major elements were analyzed on the Cameca SX50 electron microprobe at the University of California, Davis (UCD). Natural and synthetic standards were used, operating voltage was $15 \mathrm{kV}$, sample current was $10 \mathrm{nA}$, counting time was $20 \mathrm{~s}$ per element, and beam diameter was $15 \mu \mathrm{m}$. Each analysis represents an average of at least five spots from a single glass fragment. Basalt glass JDFD2 was analyzed periodically throughout the run. Table 1 compares the values obtained for basalt glass JDFD2 with preferred values obtained by microprobe and wet chemical methods (C. Langmuir and J. Bender, unpubl. data, 1992). 


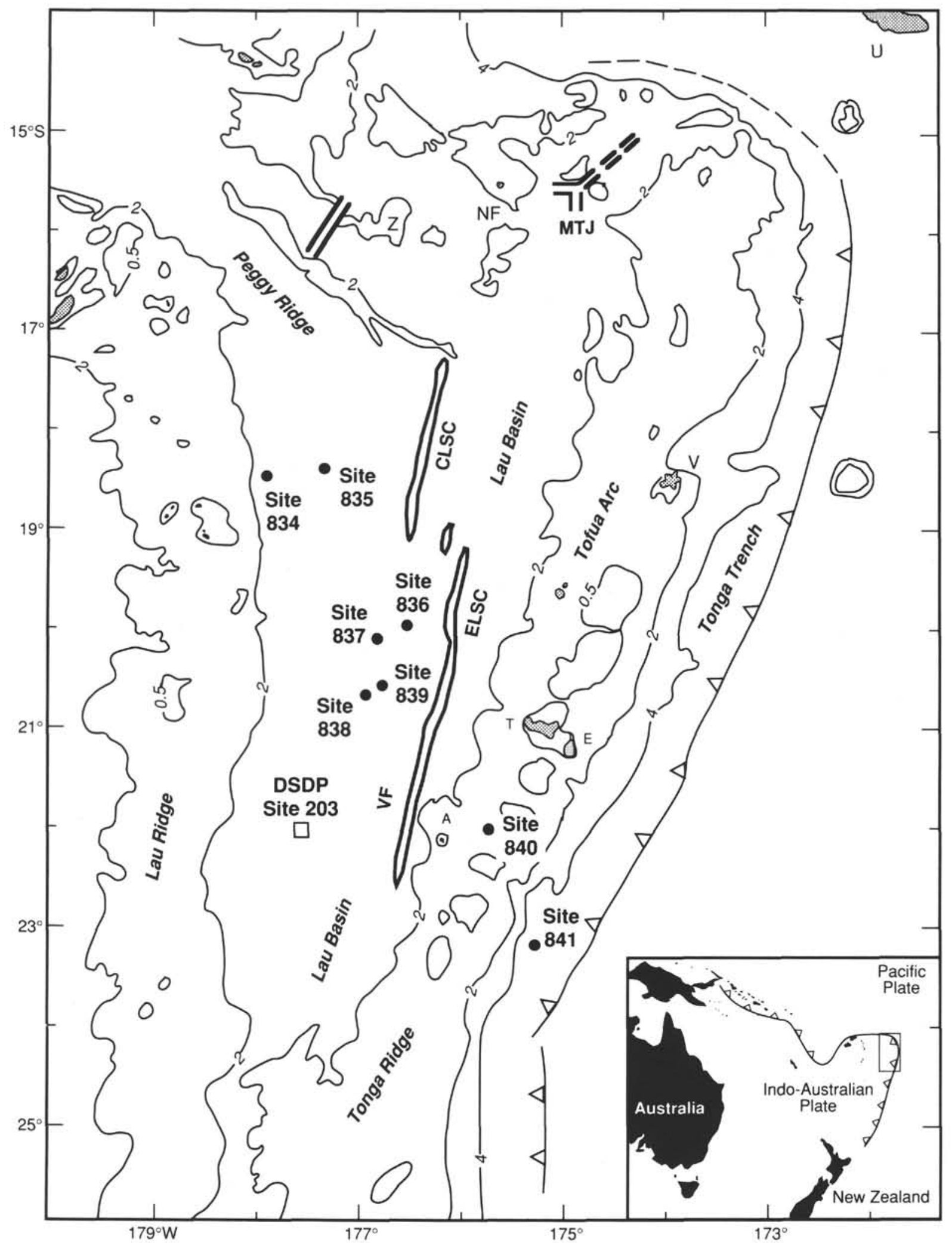

Figure 1. Map of the Lau Basin showing Sites 834, 835, 836, and 839 and the major geologic features of the Tonga Trench and the Lau Basin system. Islands shown include Zephyr Shoal (Z), Upolu (U), Tongatapu (T), 'Eua (E), Vava'u (V), 'Ata (A), and Niuafo'ou (NF). The Central Lau (CLSC) and Eastern Lau (ELSC) spreading centers, Valu Fa Ridge (VF), and Mangatolu Triple Junction (MTJ) are also shown. Contour interval in kilometers. Map from Parson, Hawkins, Allan, et al. (1992). 
Table 1. Compositions of basalt glass JDFD2 obtained by microprobe at UCD and the preferred values for this glass.

\begin{tabular}{lrrr}
\hline & $\begin{array}{c}\text { UCD } \\
\text { average }\end{array}$ & $\begin{array}{c}\text { Standard } \\
\text { deviation }\end{array}$ & $\begin{array}{r}\text { Preferred } \\
\text { value }\end{array}$ \\
\hline $\mathrm{SiO}_{2}$ & 50.33 & 0.31 & 50.80 \\
$\mathrm{TiO}_{2}$ & 1.84 & 0.06 & 1.93 \\
$\mathrm{Al}_{2} \mathrm{O}_{3}$ & 13.80 & 0.17 & 13.80 \\
$\mathrm{FeO}^{*}$ & 12.12 & 0.13 & 12.17 \\
$\mathrm{MnO}$ & 0.21 & 0.04 & 0.22 \\
$\mathrm{MgO}$ & 6.77 & 0.12 & 6.83 \\
$\mathrm{CaO}$ & 10.69 & 0.17 & 10.80 \\
$\mathrm{Na}_{2} \mathrm{O}$ & 2.87 & 0.07 & 2.77 \\
$\mathrm{~K}_{2} \mathrm{O}$ & 0.21 & 0.03 & 0.22 \\
$\mathrm{P}_{2} \mathrm{O}_{5}$ & 0.21 & 0.03 & 0.23 \\
$\mathrm{Total}^{2}$ & 99.05 & & 99.77 \\
& & &
\end{tabular}

Notes: UCD average represents 12 analyses made throughout the microprobe run. Preferred value is the preferred composition for this glass (C. Langmuir and J. Bender, unpubl. data, 1992). In Table $2 \mathrm{SiO}_{2}, \mathrm{TiO}_{2}$, and $\mathrm{Na}_{2} \mathrm{O}$ were normalized $(1 \%, 5 \%$, and $3 \%$, respectively) to correct for the small systematic differenices.

Only for $\mathrm{SiO}_{2}, \mathrm{TiO}_{2}$, and $\mathrm{Na}_{2} \mathrm{O}$ were small normalizations necessary to correct for consistent differences.

Sulfur concentrations were measured on the Camebax microprobe at the Lamont Doherty Earth Observatory (LDEO). Chalcopyrite was used as a standard, spot size was $20 \mu \mathrm{m}$, operating current was $15 \mathrm{kV}$, and sample current was $100 \mathrm{nA}$. Each analysis represents an average of four spots measured simultaneously on two spectrometers for $40 \mathrm{~s}$ (for a total of $320 \mathrm{~s}$ per glass). Replicate analyses at LDEO of basalt glass JDFD2 for S yielded an average of $1400 \pm 40 \mathrm{ppm}$, in excellent agreement with the value of $1420 \pm 40 \mathrm{ppm}$ obtained by Wallace and Carmichael (1992).

Ferrous iron was determined on glass fragments chipped from pillow margins and hand-picked to avoid alteration products, coating material, or phenocrysts. $\mathrm{Fe}^{2+}$ was determined using titration methods similar to those described by Wilson (1960). All samples were run in duplicate. $\mathrm{Fe}_{2} \mathrm{O}_{3}$ was determined by difference from $\mathrm{FeO}^{*}$ as measured by microprobe. To facilitate comparison with the large data set of Christie et al. (1986), four analyses of JDFD2 were made. The FeO values obtained (11.01 to 11.10) agree well with the $\mathrm{FeO}$ content of $11.08 \pm 0.09$ reported by Christie et al. (1986).

Even dilute acid leaches of the glass fragments appear to produce disparate and spurious $\mathrm{Fe}^{3+} / \mathrm{Fe}^{2+}$ data (K. Nilsson, unpubl. data, 1990). Extreme care was used in picking the glass fragments to ensure that no leaching was necessary. In all but one case, samples from a single geochemical unit produced very similar $f \mathrm{O}_{2}$ results. Only in basaltic glasses from Site 834 (Subunit 2a) were significant $f \mathrm{O}_{2}$ differences observed; other geochemical characteristics also suggest that this unit spans a large compositional range. In several cases, it was necessary to combine glasses from the same compositional unit to obtain enough clean material for the titrations. To determine if combining glasses from a single unit might introduce unacceptable errors, three separate glasses from Site 834 (Unit 10) and one bulk glass from this unit were analyzed. The aggregate glass $(\mathrm{FeO}=8.58)$ and the individual samples $(\mathrm{FeO}=$ 8.53 to 8.69 ) yielded similar results.

Oxygen fugacity was calculated from $\mathrm{Fe}^{3+} / \mathrm{Fe}^{2+}$ using the regression equation of Sack et al. (1980) and the coefficients of Kilinc et al. (1983). Precision of $\mathrm{fO}_{2}$ calculated in this way has been estimated to be 0.3 to $0.5 \log$ units (Kilinc et al., 1983; Carmichael, 1991). To circumvent its strong temperature dependence, $\mathrm{fO}_{2}$ is expressed relative to the curve of the nickel-nickel-oxide $f \mathrm{O}_{2}$ buffer (NNO; Huebner and Sato, 1970). Thus, positive $\triangle \mathrm{NNO}$ are relatively oxidizing conditions whereas negative $\triangle \mathrm{NNO}$ reflect more reducing conditions. The FMQ (fayalite-magnetite-quartz) buffer lies at $\Delta \mathrm{NNO}=-0.8$ (Carmichael, 1991).

\section{RESULTS}

\section{Samples}

Sites $834,835,836$, and 839 yielded fresh glass suitable for inclusion in this study (Fig. 1). Details concerning the geographic setting, water depth, and sample depth can be found in the relevant site reports in Parson, Hawkins, Allan, et al. (1992). Water depth at these sites ranged from 2450 to $2905 \mathrm{~m}$ and the samples themselves were collected from between 25 and $500 \mathrm{~m}$ below seafloor (mbsf). Units 1 , 2 , and 3 at Site 836 may not represent igneous basement (Parson, Hawkins, Allan, et al., 1992) as these glasses occurred in volcanic gravels (Units 1 and 2) and large sedimentary clasts (Unit 3 ) immediately overlying the igneous basement.

No simple relationship exists between geochemical signature and either depth or geographic position among the samples (Parson, Hawkins, Allan, et al., 1992; Hawkins and Allan, this volume; Hergt and Hawkesworth, this volume; Hergt and Nilsson, this volume). Major element variations are discussed elsewhere (e.g., Ewart, this volume; Hawkins and Allan, this volume; Hergt and Nilsson, this volume), and it will only be noted that these glasses comprise a wide range of compositions indicative of various degrees of fractionation $\left(\mathrm{SiO}_{2}=49 \%-57 \%\right.$; Table 2 ). The glasses vary in major and trace element composition from primitive basalts indistinguishable from MORB (Site 834, Unit 7) to basalts and andesites with a strong resemblance to IAV lavas (Site 839, all units).

Detailed petrographic descriptions are presented in the relevant site reports (Parson, Hawkins, Allan, et al., 1992), but those characteristics that pertain to this study will be briefly summarized. Oxide minerals are common as skeletal grains interstitial to silicate minerals, but they are extremely rare as phenocrysts. In ferroandesites from Site 834, Unit 12 (hereafter referred to as Unit 834-12), euhedral titanomagnetite grains occur in the glassy rim, suggesting that this was a liquidus phase at the time of eruption. Only in the two relatively coarse-grained diabasic units (834-5 and 836-4) do relatively large crystals of ilmenite and magnetite coexist. Although some lamellae reflecting oxyexsolution are present, their development is not extensive.

Only two basaltic units (834-7 and 834-6a) have Fe-sulfide blebs coexisting with basaltic glass. Sulfides are, however, fairly common in the crystalline interiors of most rock types, where they are often observed adjacent to or (rarely) included in plagioclase phenocrysts. Sulfides are mostly pyrrhotite and chalcopyrite compositions (K. Nilsson, unpubl. data, 1992), similar in composition to sulfide globules found in other seafloor lavas (Mathez and Yeats, 1976; Czamanske and Moore, 1977; Mathez, 1980; Perfit and Fornari, 1983).

\section{Oxygen Fugacity}

The $\mathrm{Fe}^{3+} / \Sigma \mathrm{Fe}$ ratio ranges from 0.103 to 0.286 in these glasses, corresponding to a range in $\triangle \mathrm{NNO}$ of -1.37 to +1.02 (Table 3 ). At a given $\mathrm{MgO}$ content, these $\mathrm{BABB}$ glasses are 1 to $2 \log$ units more oxidized and the range in $f \mathrm{O}_{2}$ is greater than in MORB glasses (Fig. 2). The $\mathrm{Fe}^{3+} / \mathrm{Fe}^{2+}$ ratio of some of the Leg 135 samples infers conditions more oxidized than the NNO buffer and is therefore higher than has been measured in any other deep-sea glasses. Some of the samples from Site 834 may suggest a parallel trend to MORB at approximately $1 \log$ unit higher $\mathrm{fO}_{2}$. The scatter among the data set as a whole with respect to $\mathrm{MgO}-f \mathrm{O}_{2}$ variations indicates that the $f \mathrm{O}_{2}$ variations do not reflect rock types or degree of fractionation but must largely reflect variations in the $f \mathrm{O}_{2}$ of the source.

\section{Sulfur}

Sulfur concentrations range from 90 to $1140 \mathrm{ppm}$ (Table 2) and only the basaltic glasses from Units 834-7, 834-6a, 835-1, 836-3, and 836-4 have $\mathrm{Fe}-\mathrm{S}$ relationships that place them near the empirically 
Table 2. Major element (in wt \%) and sulfur concentrations (in ppm) in Leg 135 backarc glasses.

\begin{tabular}{|c|c|c|c|c|c|c|c|c|c|c|c|c|c|}
\hline $\begin{array}{l}\text { Core, section, } \\
\text { interval }(\mathrm{cm})\end{array}$ & $\begin{array}{l}\text { Unit or } \\
\text { subunit }\end{array}$ & $\mathrm{SiO}_{2}$ & $\mathrm{TiO}_{2}$ & $\mathrm{Al}_{2} \mathrm{O}_{3}$ & $\mathrm{FeO}$ & $\mathrm{MnO}$ & $\mathrm{MgO}$ & $\mathrm{CaO}$ & $\mathrm{Na}_{2} \mathrm{O}$ & $\mathrm{K}_{2} \mathrm{O}$ & $\mathrm{P}_{2} \mathrm{O}_{5}$ & Total & $\mathrm{S}$ \\
\hline \multicolumn{14}{|l|}{$135-834 \mathrm{~A}-$} \\
\hline $13 \mathrm{X}-1,18-024$ & $2 a$ & 50.62 & 1.71 & 16.24 & 9.90 & 0.16 & 6.27 & 11.12 & 3.47 & 0.17 & 0.24 & 99.90 & 1080 \\
\hline $14 \mathrm{X}-1,25-31$ & $2 \mathrm{a}$ & 51.57 & 1.60 & 16.01 & 10.20 & 0.18 & 5.78 & 10.57 & 3.33 & 0.20 & 0.20 & 99.64 & 740 \\
\hline \multicolumn{14}{|l|}{$135-834 \mathrm{~B}-$} \\
\hline $14 \mathrm{R}-1,28-32$ & $6 a$ & 52.34 & 1.96 & 15.71 & 10.42 & 0.18 & 5.59 & 9.99 & 3.77 & 0.18 & 0.25 & 100.39 & 1140 \\
\hline $15 \mathrm{R}-1,0-8$ & $6 \mathrm{~b}$ & 50.79 & 1.29 & 16.38 & 9.19 & 0.17 & 6.72 & 11.66 & 2.93 & 0.22 & 0.21 & 99.56 & 540 \\
\hline $15 \mathrm{R}-2,35-37$ & $6 a$ & 52.20 & 2.00 & 15.64 & 10.21 & 0.16 & 5.61 & 9.94 & 3.81 & 0.18 & 0.28 & 100.03 & 1120 \\
\hline $15 \mathrm{R}-2,96-104$ & $6 a$ & 52.16 & 1.95 & 15.59 & 10.36 & 0.18 & 5.50 & 9.94 & 3.85 & 0.19 & 0.25 & 99.97 & 1140 \\
\hline $18 \mathrm{R}-1,0-6$ & $6 \mathrm{c}$ & 51.55 & 1.39 & 16.55 & 8.70 & 0.13 & 6.86 & 10.91 & 3.37 & 0.18 & 0.20 & 99.84 & 800 \\
\hline $18 \mathrm{R}-1,7-13$ & $6 c$ & 51.83 & 1.44 & 16.73 & 8.65 & 0.12 & 6.90 & 10.77 & 3.37 & 0.19 & 0.20 & 100.20 & 830 \\
\hline $19 \mathrm{R}-1,5-10$ & $6 c$ & 51.76 & 1.41 & 16.74 & 8.68 & 0.18 & 6.58 & 10.85 & 3.39 & 0.17 & 0.20 & 99.96 & 800 \\
\hline $22 \mathrm{R}-1,41-46$ & 7 & 50.12 & 1.37 & 16.53 & 8.87 & 0.17 & 8.32 & 11.76 & 3.12 & 0.07 & 0.15 & 100.49 & 1020 \\
\hline $26 \mathrm{R}-1,107-109$ & 7 & 49.97 & 1.44 & 16.53 & 8.95 & 0.16 & 8.26 & 11.92 & 3.14 & 0.09 & 0.16 & 100.62 & 1020 \\
\hline $30 \mathrm{R}-2,98-104$ & 7 & 50.09 & 1.35 & 16.53 & 9.01 & 0.18 & 8.08 & 11.91 & 2.95 & 0.09 & 0.14 & 100.34 & 1010 \\
\hline $31 \mathrm{R}-1,98-104$ & 7 & 50.23 & 1.43 & 16.46 & 8.87 & 0.16 & 8.28 & 12.03 & 3.16 & 0.09 & 0.16 & 100.87 & 1010 \\
\hline $31 R-2,37-42$ & 7 & 49.62 & 1.45 & 16.35 & 8.94 & 0.16 & 8.28 & 12.00 & 3.12 & 0.07 & 0.15 & 100.14 & 1010 \\
\hline $31 R-2,43-48$ & 7 & 50.12 & 1.41 & 16.42 & 8.82 & 0.17 & 8.21 & 11.91 & 3.15 & 0.08 & 0.16 & 100.44 & 1010 \\
\hline $32 \mathrm{R}-1,0-5$ & 7 & 49.44 & 1.37 & 16.64 & 9.10 & 0.16 & 8.23 & 11.83 & 3.14 & 0.08 & 0.15 & 100.16 & 1040 \\
\hline $33 R-1,0-6$ & 7 & 50.32 & 1.43 & 16.44 & 8.71 & 0.17 & 8.22 & 11.75 & 3.06 & 0.10 & 0.18 & 100.39 & 1000 \\
\hline $34 R-2,60-63$ & 8 & 52.49 & 1.27 & 16.36 & 9.24 & 0.16 & 6.16 & 10.96 & 3.05 & 0.11 & 0.14 & 99.94 & 620 \\
\hline $35 \mathrm{R}-1,15-23$ & 8 & 52.66 & 1.35 & 16.28 & 8.85 & 0.15 & 6.43 & 10.88 & 3.01 & 0.10 & 0.13 & 99.84 & 650 \\
\hline $35 R-1,31-37$ & 8 & 52.36 & 1.26 & 16.29 & 8.88 & 0.15 & 6.30 & 10.93 & 3.09 & 0.13 & 0.13 & 99.52 & 580 \\
\hline $35 R-2,67-69$ & 8 & 52.23 & 1.25 & 16.41 & 8.99 & 0.19 & 6.42 & 11.10 & 3.06 & 0.12 & 0.10 & 99.86 & 640 \\
\hline $35 \mathrm{R}-2,70-72$ & 8 & 52.35 & 1.29 & 16.31 & 8.94 & 0.13 & 6.45 & 11.13 & 2.98 & 0.10 & 0.09 & 99.77 & 680 \\
\hline $35 \mathrm{R}-2,77-83$ & 8 & 52.36 & 1.28 & 16.31 & 8.89 & 0.18 & 6.45 & 11.01 & 2.93 & 0.10 & 0.11 & 99.63 & 680 \\
\hline $36 \mathrm{R}-1,0-7$ & 8 & 52.40 & 1.25 & 16.50 & 8.76 & 0.12 & 6.44 & 10.99 & 3.00 & 0.12 & 0.11 & 99.70 & 660 \\
\hline $36 \mathrm{R}-1,7-10$ & 8 & 52.32 & 1.28 & 16.38 & 8.92 & 0.16 & 6.37 & 11.16 & 2.99 & 0.12 & 0.11 & 99.80 & 640 \\
\hline $37 \mathrm{R}-2,42-44$ & $10 a^{*}$ & 55.57 & 2.01 & 15.36 & 10.56 & 0.16 & 4.09 & 7.72 & 3.52 & 0.29 & 0.32 & 99.61 & 420 \\
\hline $39 \mathrm{R}-1,0-7$ & $10 \mathrm{a}$ & 51.97 & 1.69 & 15.32 & 11.33 & 0.18 & 5.02 & 9.56 & 3.51 & 0.25 & 0.21 & 99.04 & 590 \\
\hline $39 \mathrm{R}-1,7-10$ & $10 \mathrm{a}$ & 53.04 & 1.71 & 15.23 & 11.38 & 0.19 & 4.92 & 9.45 & 3.41 & 0.27 & 0.20 & 99.80 & 580 \\
\hline $39 \mathrm{R}-1,9-15$ & $10 \mathrm{a}$ & 52.33 & 1.68 & 15.31 & 11.49 & 0.21 & 4.94 & 9.48 & 3.46 & 0.28 & 0.23 & 99.40 & 570 \\
\hline $40 \mathrm{R}-1,45-47$ & $10 \mathrm{a}$ & 52.37 & 1.79 & 15.28 & 11.47 & 0.19 & 4.74 & 9.32 & 3.52 & 0.28 & 0.21 & 99.16 & 570 \\
\hline $41 \mathrm{R}-1,0-5$ & $10 \mathrm{a}$ & 53.21 & 1.76 & 15.31 & 11.55 & 0.21 & 4.67 & 9.22 & 3.41 & 0.28 & 0.24 & 99.86 & 580 \\
\hline $47 \mathrm{R}-1,130-135$ & 12 & 55.54 & 2.15 & 14.70 & 12.75 & 0.25 & 3.38 & 7.29 & 3.18 & 0.22 & 0.31 & 99.77 & 740 \\
\hline $50 \mathrm{R}-1,87-92$ & 12 & 56.06 & 2.21 & 14.54 & 12.56 & 0.27 & 3.24 & 7.35 & 3.03 & 0.23 & 0.28 & 99.77 & 760 \\
\hline $51 R-1,10-15$ & 12 & 56.15 & 2.25 & 14.55 & 12.79 & 0.28 & 3.34 & 7.32 & 3.01 & 0.22 & 0.28 & 100.19 & 780 \\
\hline $53 \mathrm{R}-1,7-20$ & 12 & 55.08 & 2.18 & 14.52 & 12.84 & 0.25 & 3.69 & 7.68 & 3.22 & 0.20 & 0.29 & 99.95 & 690 \\
\hline $54 \mathrm{R}-1,0-5$ & 12 & 55.59 & 2.31 & 14.75 & 12.92 & 0.24 & 3.65 & 7.43 & 2.99 & 0.21 & 0.28 & 100.37 & 770 \\
\hline $54 \mathrm{R}-1,5-10$ & 12 & 55.10 & 2.25 & 14.69 & 12.97 & 0.25 & 3.62 & 7.49 & 3.16 & 0.23 & 0.27 & 100.03 & 800 \\
\hline $57 R-1,0-5$ & 12 & 54.80 & 2.25 & 14.62 & 12.87 & 0.25 & 3.60 & 7.47 & 3.14 & 0.21 & 0.28 & 99.50 & 780 \\
\hline $56 \mathrm{R}-2,111-118$ & 13 & 51.26 & 1.38 & 16.16 & 9.56 & 0.17 & 6.59 & 11.44 & 3.12 & 0.13 & 0.14 & 99.94 & 780 \\
\hline $57 \mathrm{R}-1,34-40$ & 13 & 51.20 & 1.33 & 16.11 & 9.44 & 0.16 & 6.62 & 11.32 & 3.06 & 0.13 & 0.13 & 99.49 & 780 \\
\hline $59 \mathrm{R}-2,30-32$ & 13 & 51.34 & 1.30 & 16.07 & 9.52 & 0.16 & 6.33 & 11.14 & 3.18 & 0.13 & 0.17 & 99.35 & 750 \\
\hline $59 \mathrm{R}-2,52-55$ & 13 & 51.02 & 1.38 & 16.18 & 9.45 & 0.15 & 6.49 & 11.32 & 3.06 & 0.13 & 0.15 & 99.34 & 740 \\
\hline \multicolumn{14}{|l|}{$135-835 \mathrm{~B}-$} \\
\hline $3 R-1,123-127$ & 1 & 51.86 & 1.07 & 15.43 & 10.18 & 0.16 & 6.53 & 11.17 & 2.42 & 0.21 & 0.11 & 99.14 & 1070 \\
\hline $3 R-2,0-4$ & 1 & 51.86 & 1.04 & 15.52 & 10.22 & 0.14 & 6.41 & 11.25 & 2.39 & 0.21 & 0.09 & 99.12 & 1080 \\
\hline $4 \mathrm{R}-1,67-73$ & $i$ & 52.55 & 1.10 & 15.47 & 10.25 & 0.18 & 6.51 & 11.26 & 2.43 & 0.20 & 0.08 & 100.02 & 1040 \\
\hline $4 \mathrm{R}-1,73-78$ & 1 & 52.36 & 1.67 & 15.31 & 11.48 & 0.25 & 4.97 & 9.51 & 3.53 & 0.28 & 0.17 & 99.52 & 450 \\
\hline $5 \mathrm{R}-1,14-21$ & 1 & 51.91 & 1.12 & 15.61 & 10.04 & 0.19 & 6.51 & 11.23 & 2.34 & 0.19 & 0.14 & 99.28 & 1090 \\
\hline $7 R-3,135-140$ & 1 & 52.29 & 1.02 & 15.70 & 10.15 & 0.17 & 6.43 & 11.26 & 2.49 & 0.22 & 0.13 & 99.87 & 1080 \\
\hline $135-836 \mathrm{~A}$ - & & & & & & & & & & & & & \\
\hline $3 \mathrm{H}-3,23-24$ & 1 & 55.69 & 1.27 & 15.15 & 11.61 & 0.20 & 4.14 & 8.48 & 2.95 & 0.25 & 0.16 & 99.90 & 260 \\
\hline $3 \mathrm{H}-3,90-95$ & $i$ & 55.60 & 1.31 & 14.82 & 12.40 & 0.13 & 3.85 & 8.39 & 3.00 & 0.26 & 0.17 & 99.92 & 190 \\
\hline $3 \mathrm{H}-4,53-110$ & 2 & 57.99 & 1.15 & 14.74 & 11.34 & 0.24 & 3.26 & 7.69 & 3.26 & 0.30 & 0.17 & 100.13 & 240 \\
\hline $3 \mathrm{H}-\mathrm{CC}, 0-7$ & 3 & 49.95 & 0.89 & 15.81 & 9.29 & 0.21 & 8.38 & 13.72 & 2.19 & 0.07 & 0.06 & 100.56 & 1110 \\
\hline $4 \mathrm{H}-\mathrm{CC}, 0-13$ & 3 & 50.03 & 0.84 & 16.00 & 9.24 & 0.19 & 8.30 & 13.59 & 2.13 & 0.07 & 0.07 & 100.47 & 970 \\
\hline $7 \mathrm{X}-1,15-22$ & 4 & 49.97 & 0.89 & 15.60 & 9.00 & 0.19 & 7.94 & 13.66 & 1.97 & 0.06 & 0.07 & 99.35 & 970 \\
\hline 135-836B- & & & & & & & & & & & & & \\
\hline $3 R-1,47-52$ & $4 a$ & 50.08 & 0.90 & 15.91 & 9.22 & 0.17 & 8.54 & 13.85 & 2.17 & 0.06 & 0.08 & 100.98 & 1020 \\
\hline $9 \mathrm{M}-1,97-102$ & $?$ & 53.13 & 1.13 & 14.93 & 11.55 & 0.28 & 5.78 & 10.17 & 2.44 & 0.27 & 0.21 & 99.90 & 467 \\
\hline 35-839B- & & & & & & & & & & & & & \\
\hline $18 \mathrm{R}-1,0-6$ & 2 & 55.60 & 1.10 & 14.54 & 11.48 & 0.18 & 4.37 & 8.86 & 2.40 & 0.48 & 0.15 & 99.15 & 170 \\
\hline $19 \mathrm{R}-1,15-19$ & 3 & 53.26 & 0.69 & 16.15 & 8.61 & 0.19 & 6.76 & 11.86 & 1.80 & 0.34 & 0.08 & 99.73 & 110 \\
\hline $19 \mathrm{R}-1,38-41$ & 3 & 52.87 & 0.64 & 16.96 & 8.30 & 0.07 & 6.40 & 12.43 & 1.84 & 0.32 & 0.16 & 99.99 & 90 \\
\hline $19 \mathrm{R}-1,64-69$ & 3 & 52.98 & 0.68 & 16.35 & 8.79 & 0.19 & 6.62 & 11.96 & 1.88 & 0.35 & 0.09 & 99.89 & 100 \\
\hline $20 \mathrm{R}-1,36-41$ & 3 & 53.29 & 0.74 & 15.98 & 8.57 & 0.18 & 6.73 & 11.83 & 1.81 & 0.34 & 0.10 & 99.56 & 90 \\
\hline $21 \mathrm{R}-1,53-56$ & 3 & 52.84 & 0.70 & 15.90 & 9.17 & 0.15 & 6.78 & 12.06 & 1.77 & 0.31 & 0.06 & 99.74 & 110 \\
\hline $22 \mathrm{R}-1,19-23$ & 3 & 53.05 & 0.71 & 16.03 & 9.11 & 0.22 & 6.74 & 12.11 & 1.85 & 0.32 & 0.14 & 100.28 & 100 \\
\hline $22 \mathrm{R}-1,24-29$ & 3 & 53.11 & 0.73 & 15.76 & 8.90 & 0.18 & 6.80 & 12,18 & 1.79 & 0.29 & 0.09 & 99.84 & 100 \\
\hline $22 \mathrm{R}-1,30-36$ & 3 & 53.11 & 0.72 & 15.72 & 8.79 & 0.20 & 7.00 & 12.40 & 1.79 & 0.30 & 0.11 & 100.13 & 110 \\
\hline $23 \mathrm{R}-1,28-31$ & 3 & 53.58 & 0.70 & 15.86 & 8.94 & 0.14 & 6.96 & 12.02 & 1.81 & 0.29 & 0.11 & 100.42 & 110 \\
\hline $23 \mathrm{R}-1,32-35$ & 3 & 52.96 & 0.70 & 15.62 & 8.73 & 0.14 & 6.90 & 12.50 & 1.73 & 0.32 & 0.08 & 99.68 & 110 \\
\hline $23 \mathrm{R}-1,40-44$ & 3 & 52.76 & 0.73 & 16.08 & 8.93 & 0.14 & 6.72 & 12.10 & 1.85 & 0.34 & 0.13 & 99.79 & 110 \\
\hline $25 \mathrm{R}-1,11-16$ & 3 & 52.71 & 0.71 & 15.52 & 8.94 & 0.19 & 6.94 & 12.32 & 1.77 & 0.32 & 0.10 & 99.52 & 130 \\
\hline $25 \mathrm{R}-1,48-553$ & 4 & 53.20 & 0.82 & 15.47 & 10.08 & 0.19 & 6.31 & 11.18 & 1.80 & 0.25 & 0.09 & 99.39 & 210 \\
\hline $27 \mathrm{R}-1,29-33$ & 6 & 53.33 & 0.68 & 16.33 & 8.59 & 0.17 & 6.83 & 11.95 & 1.87 & 0.34 & 0.17 & 100.27 & 110 \\
\hline $42 \mathrm{R}-1,0-6$ & 9 & 55.38 & 1.05 & 14.41 & 11.73 & 0.21 & 4.23 & 9.05 & 2.34 & 0.49 & 0.17 & 99.03 & 260 \\
\hline
\end{tabular}


Table 3. $\mathrm{Fe}^{3+} / \Sigma \mathrm{Fe}, \mathrm{fO}_{2}, \mathrm{MgO}, \mathrm{FeO}^{*}$, and $\mathrm{S}$ concentrations in Leg 135 glasses.

\begin{tabular}{|c|c|c|c|c|c|c|c|}
\hline Site & $\begin{array}{l}\text { Unit or } \\
\text { subunit }\end{array}$ & $\begin{array}{l}\text { Core, } \\
\text { section }\end{array}$ & $\mathrm{FeO}^{\circ}$ & $\mathrm{MgO}$ & $\mathrm{Fe}^{3+} \Sigma \mathrm{Fe}$ & $\triangle \mathrm{NNO}$ & $\underset{\text { (ppm) }}{\mathrm{S}}$ \\
\hline \multirow[t]{12}{*}{834} & $2 a$ & $13 X-1$ & 9.90 & 6.20 & 0.112 & -1.29 & 1080 \\
\hline & $2 a$ & $14 \mathrm{X}-1$ & 10.20 & 5.72 & 0.223 & 0.43 & 740 \\
\hline & $6 a$ & Avg & 10.33 & 5.52 & 0.139 & -0.77 & 1140 \\
\hline & $6 c$ & Avg & 8.67 & 6.71 & 0.154 & -0.41 & 810 \\
\hline & 7 & Avg & 8.99 & 8.14 & 0.103 & -1.37 & 1010 \\
\hline & 8 & Avg & 8.89 & 6.32 & 0.171 & -0.12 & 660 \\
\hline & $10 \mathrm{a}$ & $39 \mathrm{R}-1$ & 11.33 & 4.97 & 0.286 & 1.02 & 570 \\
\hline & $10 \mathrm{a}$ & $40 \mathrm{R}-1$ & 11.47 & 4.69 & 0.278 & 0.96 & 570 \\
\hline & $10 \mathrm{a}$ & $41 \mathrm{R}-1$ & 11.55 & 4.62 & 0.281 & 1.07 & 580 \\
\hline & $10 \mathrm{a}$ & Avg & 11.45 & 4.76 & 0.282 & 1.04 & 570 \\
\hline & 12 & $57 \mathrm{R}-1$ & 12.87 & 3.57 & 0.182 & 0.01 & 780 \\
\hline & 12 & Avg & 12.88 & 3.45 & 0.177 & -0.04 & 760 \\
\hline \multirow[t]{2}{*}{836} & 1 & $3 \mathrm{H}-3$ & 12.40 & 3.81 & 0.277 & 1.11 & 190 \\
\hline & 3 & $4 \mathrm{H}-\mathrm{CC}$ & 9.24 & 8.22 & 0.131 & -0.75 & 970 \\
\hline \multirow[t]{2}{*}{839} & 3 & $19 \mathrm{R}-1$ & 8.61 & 6.69 & 0.231 & 0.76 & 110 \\
\hline & 3 & 23R-1 & 8.93 & 6.65 & 0.260 & 1.04 & 110 \\
\hline
\end{tabular}

Notes: Samples with a specific core designation can be identified by comparison with Table 2. When glass from several samples had to be combined to provide enough material for titration, the result is indicated as an average (Avg). When glasses from different samples were combined, the results for $\mathrm{S}, \mathrm{FeO}^{*}$, and $\mathrm{MgO}$ are given as average compositions.

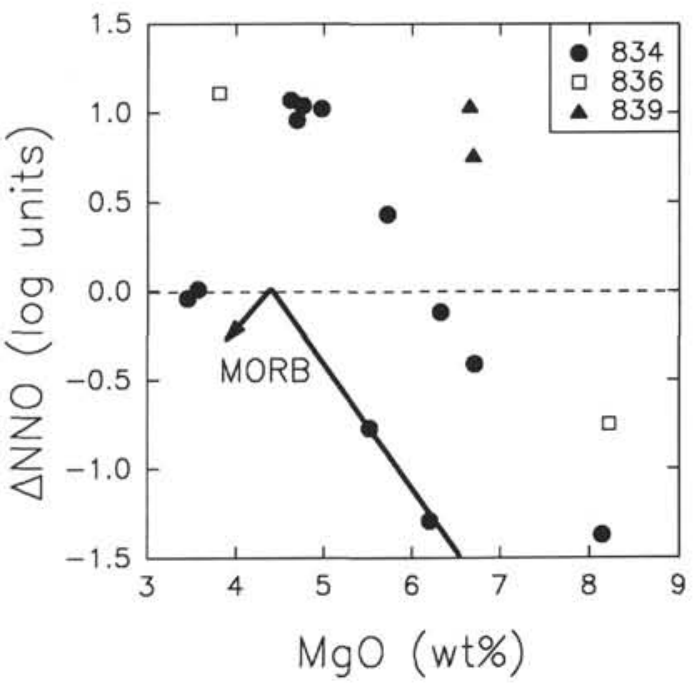

Figure 2. $\triangle \mathrm{NNO}$ vs. MgO in glass separates. Bold arrow labeled MORB is the trend that MORB glasses appear to follow during fractionation (Juster et al., 1989; Nilsson and Natland, 1991).

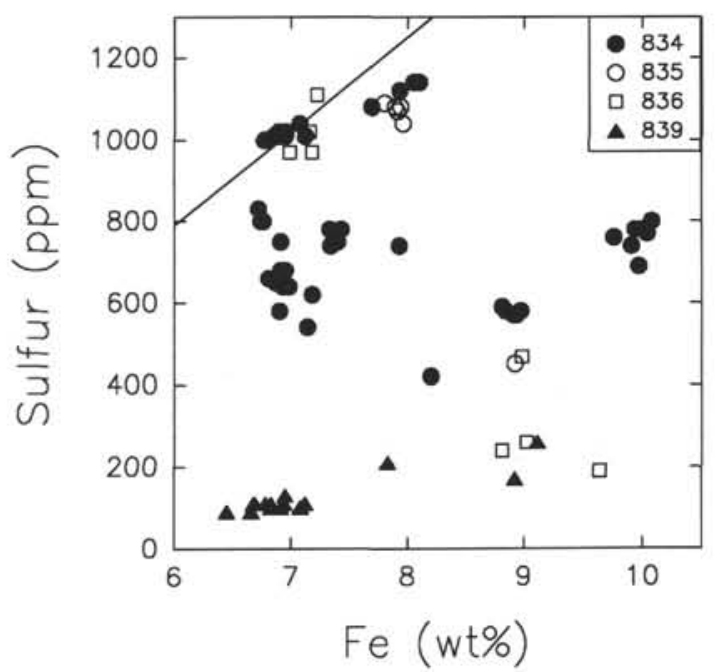

Figure $3 . \mathrm{S}$ vs. Fe in the Leg 135 glasses. Also indicated is the MORB saturation line of Mathez (1980).

(30-100 ppm), but their vesicle content is not described and their high $\mathrm{SiO}_{2}(55 \%-61 \%)$ suggests that crystallization has been extensive. The effects of vesiculation and fractionation on S concentration in IAV lavas are unknown but are likely to be significant. Studies of melt inclusions in phenocrysts suggest a tremendous range in S concentration from very low to nearly MORB-like (Anderson, 1974; Devine et al., 1984). Given the unconvincing available data, it is ambiguous whether the low $\mathrm{S}$ measured in IAV lavas is a signature of the source or simply reflects processes associated with their petrogenesis.

Many of the BABB glasses in this study are significantly different from MORB with respect to both $\mathrm{fO}_{2}$ and $\mathrm{S}$; these differences must reflect differences in their sources, their petrogenetic environments, or both. As S concentration is intimately related to $f \mathrm{O}_{2}$, the causes of the high and variable $f \mathrm{O}_{2}$ of these lavas will first be explored.

\section{Oxygen Fugacity}

Several authors have attempted to constrain fluxes of the alkali and alkaline earth elements from the descending slab so as to quantify the "subducted component" in IAV lavas (Tatsumi et al., 1986; likely to have lost much of its $\mathrm{S}$ during eruptive degassing. A single dredge in the Mariana Island Arc recovered glassy IAV material at 1170 $\mathrm{m}$ water depth (Garcia et al., 1979). These glasses also have low S 
McCullogh and Gamble, 1991; Hawkesworth et al., 1991). Quantification of these models is extremely difficult because the composition of the downgoing plate is variable and poorly constrained, the mantle wedge is variably depleted, and the effects of a volatile fluid on melting and crystallization processes in the mantle wedge are only poorly known. Nonetheless, most authors agree that an alkali-rich, hydrous fluid is driven off of the descending slab and plays a role in arc and backarc petrogenesis (e.g., Perfit et al., 1980; Gill, 1981; Hawkins and Melchior, 1985; Sinton and Fryer, 1987; Hochstaedter, Gill, and Morris, 1990; McCullogh and Gamble, 1991; Hawkesworth et al., 1991). Although the oxidizing capability of such a fluid is unconstrained, it is likely to have the capacity to increase the $\mathrm{fO}_{2}$ of the depleted mantle. This is supported by the work Mattioli et al. (1980) who showed that lherzolite nodules with mineralogic and geochemical evidence of metasomatism by a hydrous fluid have higher $f \mathrm{O}_{2}$ than unmetasomatized nodules.

If the high- $f \mathrm{O}_{2}$ Lau Basin glasses reflect the incorporation of a hydrous fluid, there should be a relationship between $f \mathrm{O}_{2}$ and those trace elements present in such a fluid. Various trace element concentrations and isotope ratios (data from Hergt and Hawkesworth, this volume) were plotted as a function of $f \mathrm{O}_{2}$ and least squares linear regressions were computed (examples in Fig. 4). If high $f \mathrm{O}_{2}$ reflects the incorporation of a hydrous fluid, the correlations should be strongest for those elements with an affinity for such fluids.

Correlation coefficients $\left(r^{2}\right)$ range from 0 to 0.85 and are listed in order of decreasing degree of correlation in Table 4. The correlation data have been subdivided into three categories: strong correlations $\left(r^{2}>0.6\right)$, possible correlations $\left(0.6>r^{2}>0.35\right)$, and no correlations $\left(r^{2}<0.35\right)$. As the $r^{2}$ values incorporate the relative errors associated with analyses of the various elements and the magnitude of the total variation in concentration, small differences between $r^{2}$ values are not as significant as the general order that is observed. The important point is that for some elements, $f \mathrm{O}_{2}$ correlates well with concentration, whereas for other elements, no correlation is observed. In particular, concentrations of the large ion lithophile elements (LILE: e.g., Rb, $\mathrm{Cs}, \mathrm{Ba}$, and $\mathrm{K}$ ) exhibit strong positive correlations with $\mathrm{fO}_{2}$ (Fig. $4 \mathrm{~A}$ ).

One should note that these calculations have not been corrected in any way for the effects of fractionation. This is not an ideal solution because other studies have concluded that some of these lavas represent moderately fractionated compositions (Parson, Hawkins, Allan, et al., 1992; Hergt and Nilsson, this volume; Ewart et al., this volume). Unfortunately, the effects of crystallization processes, on $\mathrm{Fe}^{3+} / \sum \mathrm{Fe}$ cannot be accurately predicted (Fig. 3; Juster et al., 1989). Furthermore, the variability in some trace element concentrations reflects variations beyond the effects of fractionation. Therefore, it is necessary to assume that the variability in both $\mathrm{Fe}^{3+} / \sum \mathrm{Fe}$ and some trace element concentrations is dominantly a source signature and the secondary effects of fractional crystallization have been relatively minor. This assumption is supported by the observation that the most mafic samples $(\mathrm{MgO}>6 \mathrm{wt} \%)$, those that are least likely to have been affected by fractionation processes span nearly the entire range in $f \mathrm{O}_{2}$ space (circled points in Fig. 4).

When the elements and isotope ratios are listed by decreasing $r^{2}$ values as determined above (Table 4), the order of the elements is remarkably similar to estimates of trace element affinity for a fluid phase as determined by Tatsumi et al. (1986) and McCullogh and Gamble (1991). In an experimental study evaluating trace element mobility during dehydration of serpentinite, Tatsumi et al. (1986) concluded that trace element affinity for such a fluid follows the order $\mathrm{Rb}>\mathrm{Ba}>\mathrm{K}>\mathrm{Sr}>\mathrm{La}>\mathrm{Y}$. Based on patterns observed on MORBnormalized trace element diagrams, McCullogh and Gamble (1991) suggested that trace element affinity for a slab-derived hydrous fluid follows the order $\mathrm{Rb}>\mathrm{Ba}>\mathrm{Pb}>\mathrm{K}>\mathrm{U}>\mathrm{Th}>\mathrm{Sr}>\mathrm{La}>\mathrm{Ce}>\mathrm{Nb}>$ Y. Those elements that correlate well with $f_{2}$ (particularly $\mathrm{Rb}, \mathrm{Ba}$, and $\mathrm{K}$ ) are suggested to be the most fluid-mobile elements by both models. The relatively poor $r^{2}$ values for $\mathrm{Pb}, \mathrm{Th}$, and $\mathrm{Sr}$ are rather surprising because these elements have been suggested to be relatively
Table 4. Various trace elements and isotopic ratios and the correlation coefficient $\left(r^{2}\right)$ between the concentration of that element or the ratio and $f \mathrm{O}_{2}$.

\begin{tabular}{lc}
\hline \multicolumn{1}{c}{ Element/ratio } & $r^{2}$ \\
\hline Strong correlations: & \\
$\mathrm{Rb}$ & 0.85 \\
$\mathrm{Ba}$ & 0.82 \\
$\mathrm{Cs}$ & 0.74 \\
${ }_{\mathrm{K}}{ }_{2} \mathrm{O}$ & 0.65 \\
${ }_{\mathrm{Sr}}{ }^{86} \mathrm{Sr}$ & 0.65 \\
Possible correlations: & \\
$\mathrm{U}$ & 0.58 \\
${ }_{207} \mathrm{~Pb} /{ }^{204} \mathrm{~Pb}$ & 0.48 \\
$\mathrm{~W}$ & 0.47 \\
$\mathrm{Th}$ & 0.45 \\
$\mathrm{~Pb}$ & 0.37 \\
${ }_{\mathrm{No}}^{\mathrm{Correlations:}}$ & \\
$\mathrm{Ta}$ & 0.21 \\
$\mathrm{Nb}$ & 0.15 \\
${ }_{208} \mathrm{~Pb} /{ }^{204} \mathrm{~Pb}$ & 0.15 \\
$\mathrm{Zr}$ & 0.07 \\
$\mathrm{Ce}$ & 0.06 \\
${ }_{206} \mathrm{~Pb} /{ }^{204} \mathrm{~Pb}$ & 0.05 \\
$\mathrm{La}$ & 0.03 \\
$\mathrm{Hf}$ & 0.03 \\
${ }_{43} \mathrm{Nd} /{ }^{144} \mathrm{Nd}$ & 0.02 \\
$\mathrm{Sr}$ & 0.00 \\
$\mathrm{Y}$ & 0.00 \\
$\mathrm{Ba} / \mathrm{La}$ & 0.74 \\
$\mathrm{Ce} / \mathrm{Pb}$ & 0.52 \\
$\mathrm{~S}$ & 0.80 \\
&
\end{tabular}

Notes: Trace element and isotope data are from Hergt and Hawkesworth (this volume). Note that the correlations of $\mathrm{fO}_{2}$ with $\mathrm{S}$ and $\mathrm{Ce} / \mathrm{Pb}$ are in the opposite sense as the other well-correlated elements.

mobile in a fluid phase (McCullogh and Gamble, 1991; Hawkesworth et al., 1991). The absence of a correlation between $f \mathrm{O}_{2}$ and $\mathrm{Sr}$, despite the good correlation between $f \mathrm{O}_{2}$ and ${ }^{87} \mathrm{Sr} /{ }^{86} \mathrm{Sr}$, may reflect the secondary effects of plagioclase crystallization. According to one model (McCullogh and Gamble, 1991), $\mathrm{Pb}$ is a highly mobile element, yet only a poor correlation with $f \mathrm{O}_{2}$ is observed $\left(r^{2}=0.37\right)$. Such discrepancies may reflect the model-dependent nature of fluid mobility studies or differences in subduction/dehydration regimes in individual subduction zones.

Because the effects of fractionation cannot be accounted for in the $r^{2}$ calculations, it is desirable to observe correlations in elemental and isotopic ratios. Various trace element ratios, such as high $\mathrm{Ba} / \mathrm{La}$ and low $\mathrm{Ce} / \mathrm{Pb}$, are characteristic of $1 \mathrm{AV}$ lavas and are thought to reflect the incorporation of an alkali-rich (high $\mathrm{Ba}$ and $\mathrm{Pb}$, low $\mathrm{La}$ and $\mathrm{Ce}$ ) fluid in IAV petrogenesis. As these elements are highly incompatible during melting and crystallization processes, these ratios should remain relatively constant and reflect their source even as their concentrations change. Good correlations with $\mathrm{fO}_{2}$ for both $\mathrm{Ba} / \mathrm{La}$ (positive; Fig. 4B) and $\mathrm{Ce} / \mathrm{Pb}$ (negative) support the suggestion that the elemental correlations described above are not simply a fortuitous consequence of fractionation processes. Interestingly, the correlation of $\mathrm{Ce} / \mathrm{Pb}$ with $\mathrm{fO}_{2}$ is stronger than that of either $\mathrm{Ce}$ or $\mathrm{Pb}$ alone.

Correlations with $f \mathrm{O}_{2}$ also provide insight into the behavior of radiogenic isotope ratios. The ${ }^{87} \mathrm{Sr} /{ }^{86} \mathrm{Sr}$ ratio correlates relatively well with $f \mathrm{O}_{2}\left(r^{2}=0.65\right.$; Fig. 4C), whereas no correlation is observed for the Nd isotopes $\left(r^{2}<0.1\right)$; this is consistent with the suggestion that $\mathrm{Sr}$ is carried by a fluid phase whereas Nd is not. Although there is good coherency among the $\mathrm{Pb}$ isotope ratios themselves (Hergt and Hawkesworth, this volume), the ${ }^{207} \mathrm{~Pb} /{ }^{204} \mathrm{~Pb}$ ratio shows a possible correlation with $\mathrm{fO}_{2}$, whereas no correlation is observed for the ${ }^{208} \mathrm{~Pb} /{ }^{204} \mathrm{~Pb}$ or ${ }^{206} \mathrm{~Pb} /{ }^{204} \mathrm{~Pb}$ ratios. Perhaps the "subducted component" has a stronger effect on ${ }^{207} \mathrm{~Pb} /{ }^{204} \mathrm{~Pb}$ than the other isotopes of $\mathrm{Pb}$ in the Lau Basin mantle.

Although the suggestion of an oxidized, hydrous, LILE-rich fluid derived from a descending slab is not new, this is the first relationship 


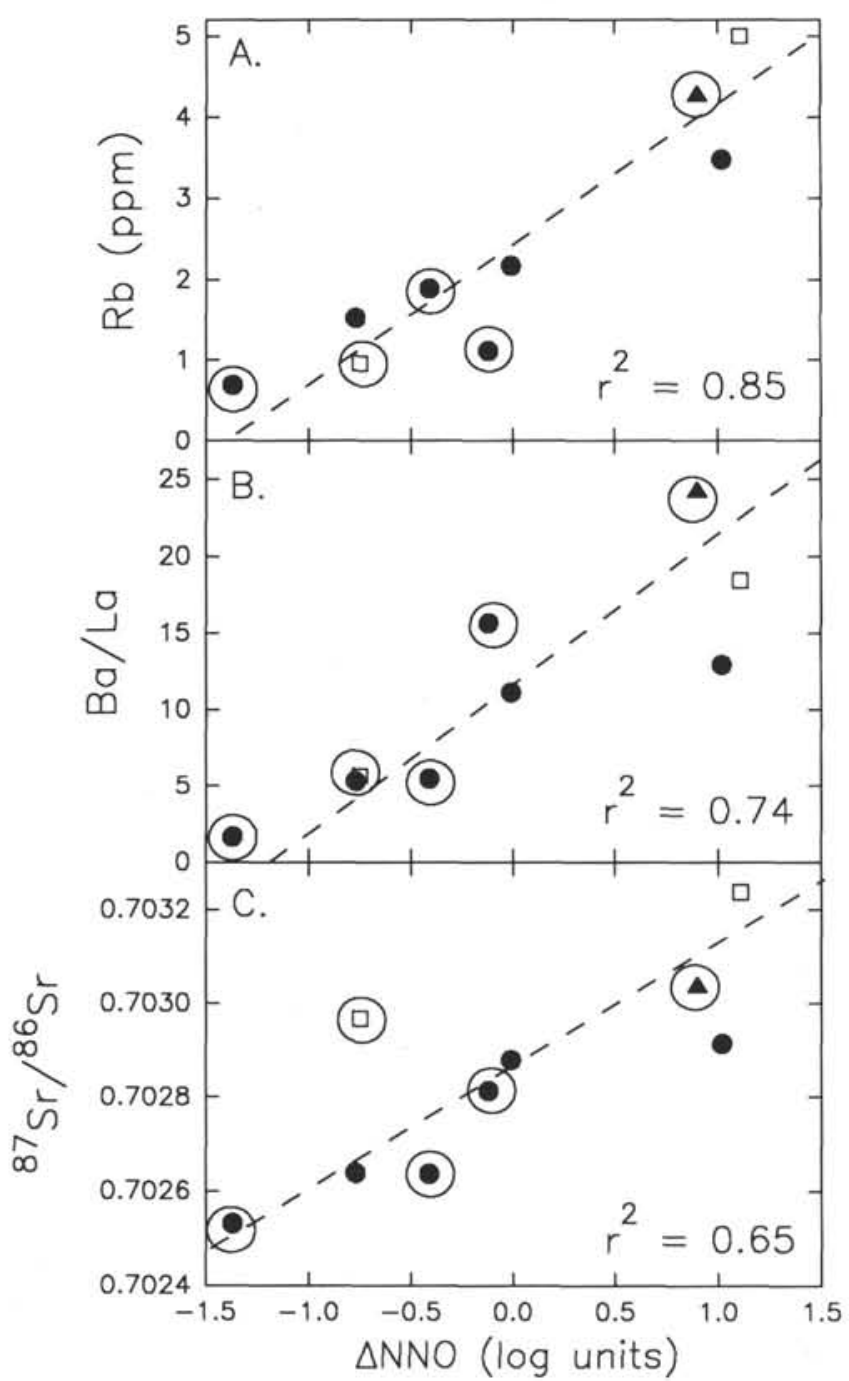

\section{- 834 836 ^ 839}

Figure 4. Rb concentration (A), $\mathrm{Ba} / \mathrm{La}(\mathbf{B})$, and ${ }^{87} \mathrm{Sr} /{ }^{86} \mathrm{Sr}$ (C) vs. $f \mathrm{O}_{2}(\Delta \mathrm{NNO})$ in Leg 135 glasses. Dashed lines are linear regressions through the data with correlation coefficients as indicated. Circled points indicate those glasses with $\mathrm{MgO}>6 \mathrm{wt} \%$. Note that these relatively high $\mathrm{MgO}$ glasses occur throughout and thus the correlations cannot result simply from the effects of fractional crystallization.

between $\mathrm{fO}_{2}$ and the elements likely to be carried by such a fluid that has been observed in basaltic glass. If the order of $r^{2}$ values is indicative of the composition of such a hydrous fluid in the Lau-Tonga system, then this component is characterized by high $f \mathrm{O}_{2}, \mathrm{Rb}, \mathrm{Ba}, \mathrm{Cs}, \mathrm{K}$, and ${ }^{87} \mathrm{Sr} /{ }^{86} \mathrm{Sr}$, and by possible enrichments in $\mathrm{U}, \mathrm{Th}, \mathrm{W}, \mathrm{Pb}$, and ${ }^{207} \mathrm{~Pb} /{ }^{204} \mathrm{~Pb}$. Those elements that show no correlation with $\mathrm{fO}_{2}\left(r^{2}<\right.$ 0.35 ) are probably not introduced by this fluid phase; their variability must reflect heterogeneities in the mantle and/or fractionation effects.

\section{Sulfur}

In this section, the low and variable $\mathrm{S}$ concentrations of these lavas will be explored. In particular, (1) As these melts are below sulfide saturation, does $S$ behave as an incompatible element? (2) Does mixing occur between high-S and low-S source components? and (3) Is the solubility of $\mathrm{S}$ decreased as a result of the elevated $f \mathrm{O}_{2}$ ? Does this lead to increased S-loss during submarine degassing?

\section{Sulfur as an Incompatible Element}

Most of the glasses do not coexist with a sulfide phase and therefore the melts from which they formed are likely to have been undersaturated with respect to sulfide melts. If $\mathrm{S}$ is exhausted during partial melting of the mantle source (e.g., Hamlyn et al., 1985; Hamlyn and Keays, 1986; Natland et al., 1991), then the resulting magmas will be below saturation. As long as sulfide-saturation is not reached during fractional crystallization and $\mathrm{S}$ does not enter into any other crystallizing phases, $\mathrm{S}$ should behave as an incompatible element (i.e., its concentration in the melt should increase in proportion with other incompatible elements). Using $\mathrm{MgO}$ as a measure of fractionation, there is clearly no consistent increase in $\mathrm{S}$ concentration with decreasing $\mathrm{MgO}$ (Fig. 5). In fact, some of the least fractionated glasses have among the highest S concentrations (e.g., Units 834-7, 836-3, and 836-4) and vice versa (e.g., Units 834-10a, 836-1, 836-2, 839-1, and 839-9).

Furthermore, $\mathrm{S}$ concentrations are not correlated with those of most incompatible elements. In particular, there is no correlation between $\mathrm{S}$ and either the rare earth elements (REE) or the high field-strength elements (HFSE; e.g., $\mathrm{Nb}, \mathrm{Ta}, \mathrm{Zr}$, and $\mathrm{Y}$ ). There is, however, a strong negative correlation between $\mathrm{S}$ content and the LILEs (e.g., Rb; Fig. 6A). Although a negative relationship between two elements cannot indicate that they are both behaving incompatibly during crystallization, it does suggest that the concentration variations are linked.

\section{Mixing}

Trace element and isotopic studies indicate that these lavas represent mixing between at least three compositional end-members: two asthenospheric components and at least one "arc-like" component (Hergt and Hawkesworth, this volume). It is therefore appealing to try to constrain the wide range of $S$ contents by mixing of low-S (arc-like) and high-S (MORB-like) sources. Excellent negative correlations are observed between $\mathrm{S}$ and LILE concentrations (e.g., Rb; Fig. 6A) and many ratios involving these elements (e.g., Ba/La; Fig. $6 \mathrm{~B})$. However, the particularly striking relationships are of the sort S/LILE vs. 1/LILE (Figs. 6C and 6D). A straight line on such a diagram is consistent with, although not conclusive evidence for, binary mixing between high-S/low-LILE and low-S/high-LILE components. The implied end-members from these diagrams are remarkably similar to what have been suggested for MORB ( 1000 ppm S, $\sim 0.05 \mathrm{wt} \% \mathrm{~K}_{2} \mathrm{O}, \sim 0.03 \mathrm{ppm} \mathrm{Rb}$, and $\left.\sim 4 \mathrm{ppm} \mathrm{Ba}\right)$ and IAV ( $\sim 50 \mathrm{ppm}$ $\mathrm{S}, \sim 0.35 \mathrm{wt} \% \mathrm{~K}_{2} \mathrm{O}, \sim 7 \mathrm{ppm} \mathrm{Rb}$, and $\sim 75 \mathrm{ppm} \mathrm{Ba}$ ). Thus, it is possible that the wide range of both $\mathrm{S}$ and LILE concentrations represent

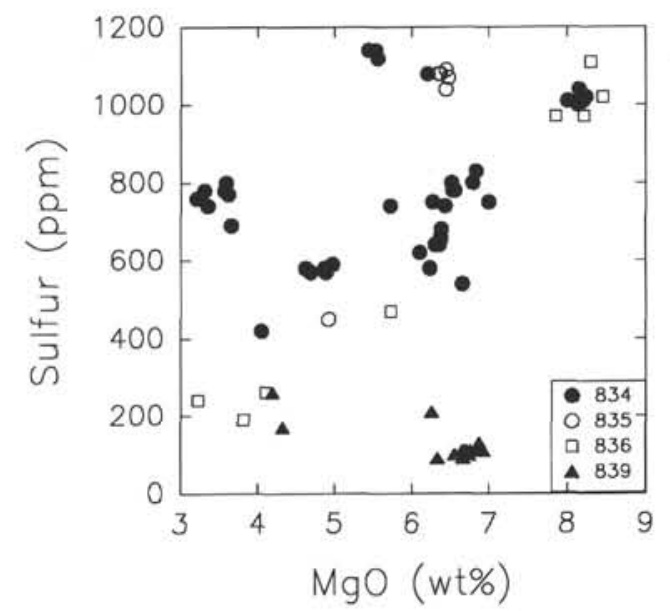

Figure 5. S vs. MgO for Leg 135 glasses. Note that $\mathrm{S}$ does not increase with decreasing $\mathrm{MgO}$ as would be expected if $\mathrm{S}$ behaves as an incompatible element. 

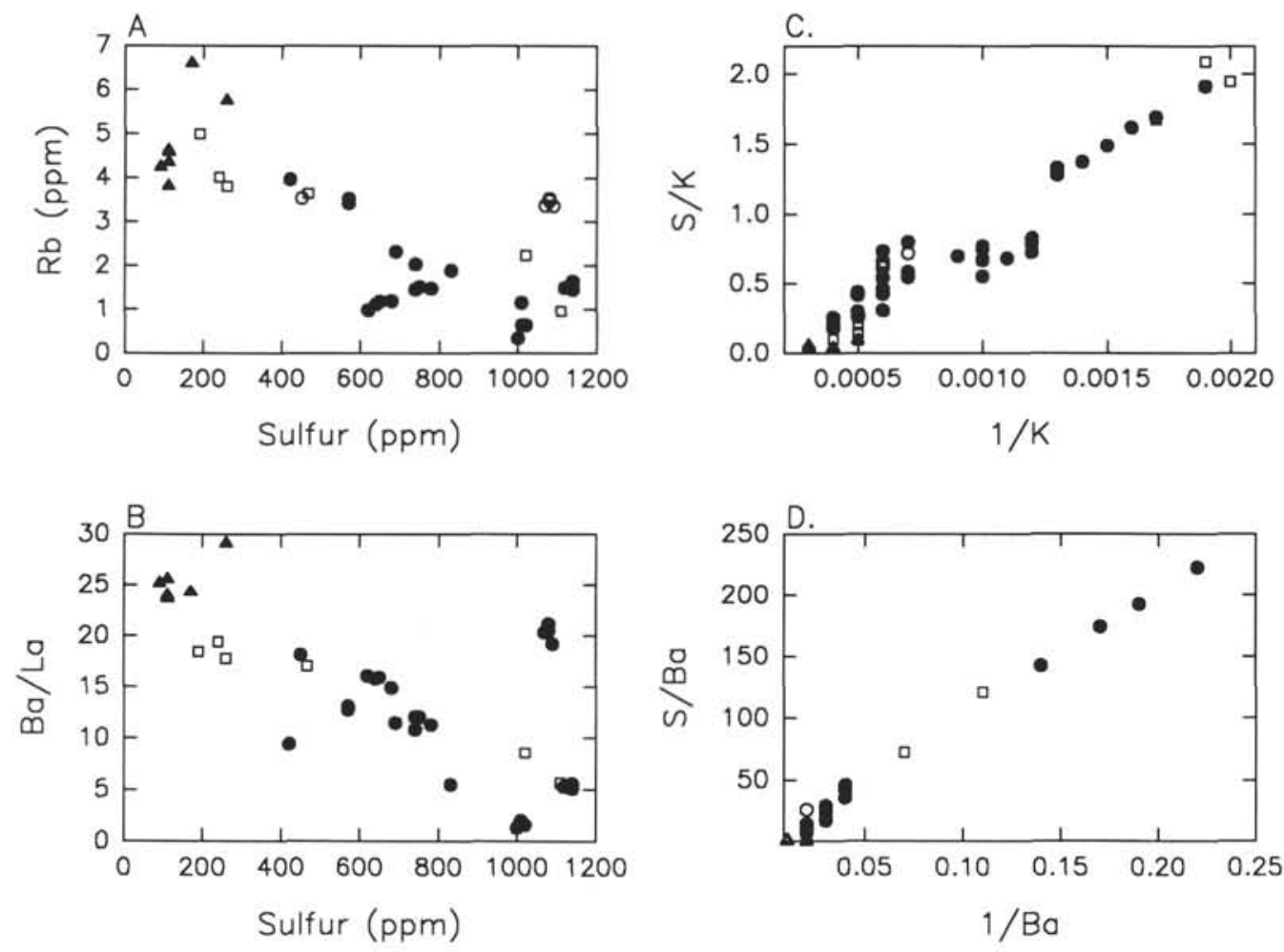

\begin{tabular}{|llll|}
\hline-834 & $\circ 835$ & 口 836 & ^ 839 \\
\hline
\end{tabular}

Figure 6. Various relationships between $\mathrm{S}$ and LILEs illustrating the general result that high LILE concentration is coupled with low $S$ and vice versa. A. $S$ vs. Rb. B. S vs. Ba/La. C. S/K vs. 1/K. D. S/Ba vs. 1/Ba.

mixing between depleted asthenosphere and a hydrous fluid introduced during subduction and dehydration of the slab.

To test this mixing hypothesis it is necessary to explore the mass balance constraints concerning the $S$ and LILE budgets of the hypothetical components. It is generally agreed that in regions of IAV and $\mathrm{BABB}$ petrogenesis, the dominant mixing component is the depleted asthenosphere and that the subducted component acts as an LILE-rich contaminant. In the case of the LILEs, it is easy to envision how the addition of a very small amount of trace element enriched fluid can mix with a large amount of trace element depleted mantle and have a tremendous effect on the resulting composition. However, with respect to $\mathrm{S}$, we must explain the opposite relationship; the arc component is apparently very low in $\mathrm{S}$, yet it must mix with a large amount of a high-S component and generate low-S melts. To satisfy mass balance constraints, negative $\mathrm{S}$ concentrations are required in the subducted component.

Another argument against the mixing hypothesis involves the relationships between $\mathrm{S}$ and other classes of trace elements which have distinctive abundances in MORB and IAV lavas. To explain the very low S content of boninites, Hamlyn et al. (1985) and Hamlyn and Keays (1986) argued that low S is a characteristic of second stage melts in which the bulk of the $\mathrm{S}$ inventory was removed during a previous partial melting event. This argument is often invoked to explain the low HFSE concentrations in IAV and BABB lavas (e.g., Gill, 1981; Hawkins et al., 1984; Hawkins and Melchior, 1985; McCullogh and Gamble, 1991). If previous depletion events control both $\mathrm{S}$ and HFSE, the relationship between $\mathrm{S}$ and HFSE should be at least as strong as that between $\mathrm{S}$ and those elements introduced during later enrichment events. The lack of any correlation between $\mathrm{S}$ and the HFSE, coupled with the excellent negative correlations between $\mathrm{S}$ and the LILEs, strongly suggest that $\mathrm{S}$ concentration is more closely related to those processes that are responsible for the enrichment of LILEs than for the depletion of HFSE. Although the excellent S-LILE relationship could theoretically be consistent with binary mixing, both the low $\mathrm{S}$ concentrations and the excellent S-LILE relationship must have another origin.

\section{Low Sulfur Solubility and Sulfur Loss During Degassing}

The relationship between $\mathrm{fO}_{2}$ and $\mathrm{S}$ solubility will be reviewed so that the significance of any relationship between $\mathrm{S}$ and $f \mathrm{O}_{2}$ for these samples can be determined. Katsura and Nagashima (1974) concluded that the solubility of S (with respect to silicate-vapor equilibria) in magmas of various compositions is strongly dependent on $\mathrm{fO}_{2}$ and reaches a minimum at $f \mathrm{O}_{2}$ of approximately NNO (their fig. 3). Furthermore, at $f \mathrm{O}_{2}$ lower than NNO, $\mathrm{S}$ is dissolved in the melt as $\mathrm{S}^{2-}$ and behaves as observed in MORB. At $f \mathrm{O}_{2}$ greater than NNO, much of the $\mathrm{S}$ dissolves as $\mathrm{SO}_{4}^{2-}$ (Sakai et al., 1982; Carroll and Rutherford, 1988; Nilsson and Peach, 1993) and the effects on basaltic magma are essentially unexplored.

The term "solubility" in the petrologic literature refers to the S content of the silicate melt in equilibrium with another S-rich phase (sulfide liquid, anhydrite, or a vapor phase). The Lau Basin magmas are, for the most part, undersaturated with respect to a sulfide liquid, as evidenced by the near absence of sulfide globules and the lack of a relationship between $\mathrm{S}$ and $\mathrm{Fe}$. In addition, there is no evidence that these magmas were saturated with anhydrite, which might result in a relationship between $\mathrm{S}$ and $\mathrm{Ca}$ (Carroll and Rutherford, 1985, 1987). If the Lau Basin magmas were controlled by silicate-vapor systematics, the experimental results of Katsura and Nagashima (1974) are applicable as these experiments were saturated only with an S-bearing vapor phase.

Significantly, a strong negative correlation $\left(r^{2}=0.80\right)$ is present between $\mathrm{S}$ concentration and oxidation state in the Lau Basin glasses (Fig. 7), suggesting that the two parameters are intimately related. S concentration decreases steadily with increasing $\mathrm{fO}_{2}$ until approximately $\mathrm{NNO}+1$. These oxidized lavas are likely to be recording the 
minimum in S solubility, which occurs at approximately NNO (Katsura and Nagashima, 1974). In addition to the decreased solubility of $\mathrm{S}$ in these oxidized melts, any degree of submarine degassing could further decrease the magmatic $\mathrm{S}$ concentrations.

Previous studies of volatile behavior during submarine degassing have concluded that at water depths greater than 200-500 m degassing is dominated by $\mathrm{CO}_{2} ; \mathrm{H}_{2} \mathrm{O}$ and $\mathrm{S}$ are not lost in appreciable quantities at these pressures (e.g., Moore and Fabbi, 1971; Moore and Schilling, 1973; Dixon et al., 1991). However, the degassing behavior of various volatile species from oxidized, volatile-rich lavas such as those recovered on Leg 135 is essentially unknown. Insufficient data are available on other volatile constituents in these lavas to make more than intuitive inferences regarding degassing, but the high vesicle contents (approaching $50 \mathrm{vol} \%$ in some glasses; Parson, Hawkins, Allan, et al., 1992) suggest that degassing processes might be quite different in these backarc lavas than in MORB. A relationship between $\mathrm{S}$ concentration and extent of degassing is supported by a crude negative relationship between vesicles and average $\mathrm{S}$ concentration for a given geochemical unit (Fig. 8). Using vesicle contents of nearby whole rocks as a proxy for degree of degassing is somewhat risky. Low vesicle contents can indicate both undegassed or highly degassed magmas and vesicle content varies by as much as 20 vol\% within some of the geochemical units (Parson, Hawkins, Allan, et al., 1992). The relatively low vesicle contents of the Site 839 lavas (given their extremely low S) may suggest that they have already undergone extensive degassing. More data on the behavior of other volatiles in these lavas are crucial before quantitative conclusions concerning degassing of these melts can be made.

In conclusion, the low S concentrations of the "arc-like" samples (particularly those from Site 839) probably reflect the effects of a petrogenetic process rather than a source characteristic. If LILEs are introduced into the Lau Basin mantle by a hydrous fluid, the introduction of this fluid into the mantle may also increase the $f_{2}$. High $\mathrm{fO}_{2}$ lowers the solubility of $\mathrm{S}$, which could promote $\mathrm{S}$ loss during magmatic degassing. Thus, the low $\mathrm{S}$ concentrations in many of these glasses reflect the higher $f \mathrm{O}_{2}$ of the supra-subduction zone environment and not a low-S source.

\section{Comparison to Other Backarc Glasses}

Although a small amount of $S$ data for various other BABB exists in the literature, they are not coupled with $\mathrm{fO}_{2}$ data and therefore cannot be compared directly to the results of this study. Despite the uncertainties introduced by combining $S$ data generated by various analytical methods (e.g., Dixon et al., 1991), the available data from various backarc basins have been combined to ascertain whether the low and variable $S$ concentrations observed in the Leg 135 glasses are anomalous (Fig. 9). Although S concentrations from no single data set suggest any correlation with $\mathrm{Fe}$, the combined data indicate that most BABB magmas show a reasonable correlation between $\mathrm{S}$ and Fe. Interestingly, the backarc samples always fall at lower $\mathrm{S}$ for a given Fe content than do MORB glasses. This relationship is as would be expected if additional $\mathrm{Fe}^{3+}$ acts simply as a dilutant with respect to the Fe-S relationship of Mathez $(1976,1980)$. Simple calculations suggest that the trend observed in Figure 9 is the trend that is predicted given a $\mathrm{Fe}^{3+} / \Sigma \mathrm{Fe}$ of approximately 0.2 (Nilsson, 1993). Although careful $\mathrm{nO}_{2}$ studies of BABB glasses are rare, this $\mathrm{Fe}^{3+} / \sum \mathrm{Fe}$ is approximately what has been observed and suggested (Hawkins and Melchior, 1985; Hochstaedter, Gill, Kusakabe, et al., 1990; Nilsson, 1993). No explanation can be given for the very low $S$ concentrations from some of these localities, as the $\mathrm{fO}_{2}$ and degree of degassing at most sites were not determined. It is possible that the low $\mathrm{S}$ in other backarc basins may be caused by low S solubility as a result of high $\mathrm{fO}_{2}$ and that loss of $\mathrm{S}$ species from arc and backarc lavas during degassing may be a widespread phenomenon (even at considerable water depths).

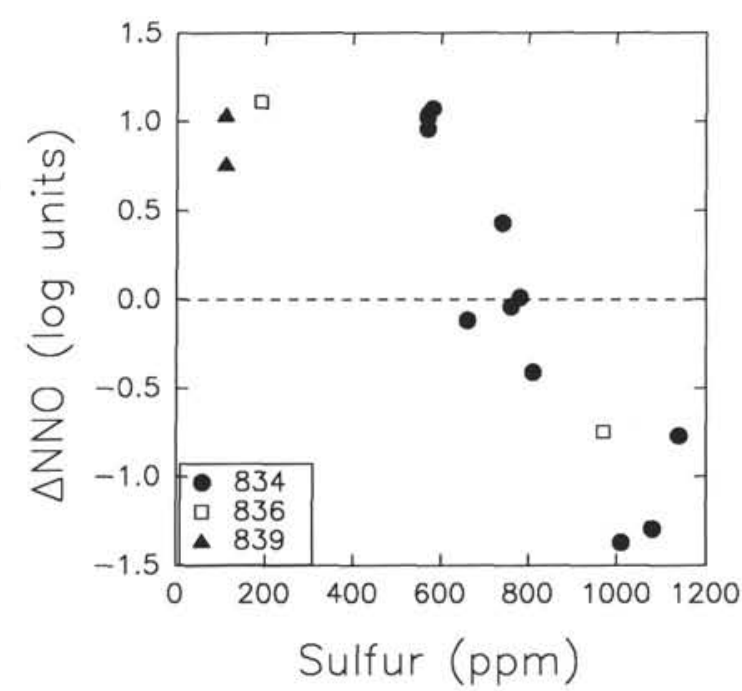

Figure 7. Sulfur vs. $\triangle$ NNO.

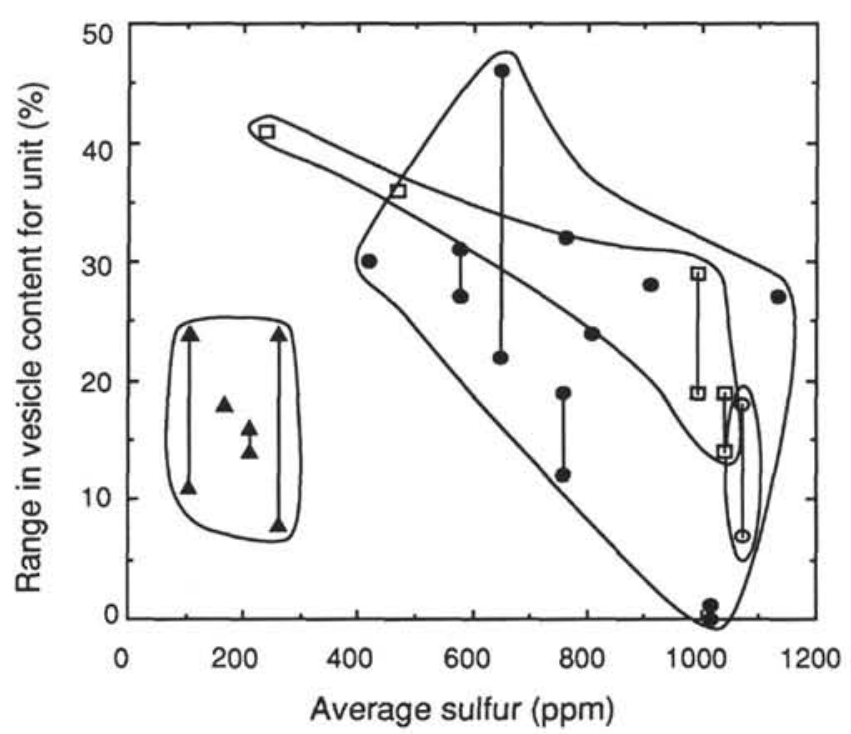

Figure 8. Average $\mathrm{S}$ concentration vs. range in vesicle content for each unit. Vesicle content (vol\%) is the range determined by point counts of nearby samples (Parson, Hawkins, Allan et al., 1992). Lines connect points at the extremes of vesicle contents for each unit and single points indicate that only one sample was counted from that unit. Fields enclose points from the same site. Symbols as in previous figures.

\section{CONCLUSIONS}

The Leg 135 backarc glasses are characterized by relatively high and variable $\mathrm{Fe}^{3+} / \mathrm{Fe}^{2+}$ (and therefore $f \mathrm{O}_{2}$ ). A strong correlation between $f \mathrm{O}_{2}$ and the LILEs (and ${ }^{87} \mathrm{Sr}{ }^{86} \mathrm{Sr}$ ) suggests that a high $f \mathrm{O}_{2}$-high LILE component may be involved in the petrogenesis of these magmas. When the elements and ratios are ranked in order of decreasing degree of correlation with $f \mathrm{O}_{2}$, the order is remarkably similar to suggested trace element fluid mobility generated by "slab flux" models (e.g., Tatsumi et al., 1986; McCullogh and Gamble, 1991; Hawkesworth et al., 1991). The high- $f \mathrm{O}_{2}$, high-LILE component is therefore suggested to be a hydrous fluid produced during slab dehydration.

Sulfur concentration in the Leg 135 glasses is low and variable and is not coupled with $\mathrm{FeO}^{*}$ as it is in MORB glasses. $\mathrm{S}$ does correlate negatively with both $\mathrm{fO}_{2}$ and the LILEs. The correlation is in the 


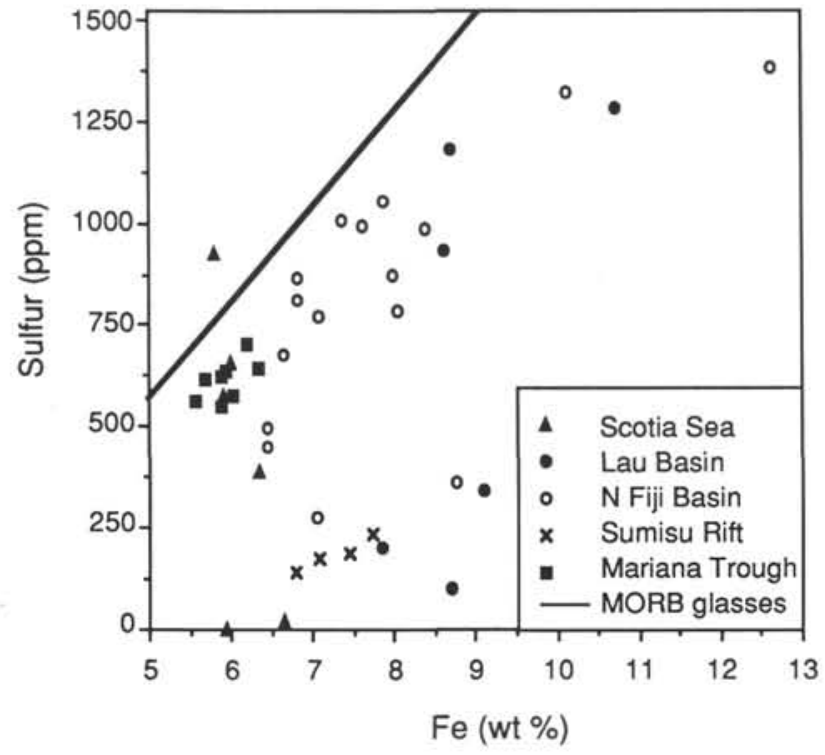

Figure $9 . \mathrm{S}$ vs. Fe for other backarc basin data. MORB saturation line from Mathez (1980). Data sources are as follows: Scotia Sea=Muenow et al. (1980); Lau Basin = Davis et al. (1991); North Fiji Basin = Aggrey et al. (1988); Sumisu Rift $=\mathrm{S}$ from Hochstaedter, Gill, Kusakabe, et al. (1990) and $\mathrm{FeO}^{\circ}$ from Hochstaedter, Gill, and Morris, (1990); Mariana Trough = S from Kusakabe et al. (1990) and $\mathrm{FeO}^{*}$ from J. Hawkins (unpubl. data, 1988).

wrong sense to record incompatible behavior and does not extend to other trace elements and isotope ratios as it should if mixing were involved. S solubility is strongly dependent on $\mathrm{fO}_{2}$ and the low S concentrations reflect the high $f \mathrm{O}_{2}$ of these glasses.

The low- $f \mathrm{O}_{2}$ glasses (i.e., Unit 834-7) suggest very little influence of an alkali-rich, high- $f \mathrm{O}_{2}$, hydrous fluid; their major and trace element characteristics are much like MORB, S concentrations are high, and they are saturated with a sulfide melt. Conversely, the high- $f \mathrm{O}_{2}$ glasses (i.e., those from Site 839) record the significant influence of such a hydrous fluid. The LILEs are enriched, $f \mathrm{O}_{2}$ is relatively high, $\mathrm{S}$ solubility is low and much of the $\mathrm{S}$ has been lost during degassing.

We must await more detailed studies of other $\mathrm{BABB}$ with coupled $\mathrm{S}$ and $f \mathrm{O}_{2}$ data before determining if such a process is of global significance in backarc basins and island arcs.

\section{ACKNOWLEDGMENTS}

Support for this work was provided by USSAC. The microprobe work benefited from the assistance of Sarah Roeske and Linnea Norby at UCD and LDEO, respectively. Careful reviews by Cheryl Peach, Ken Farley, Ed Mathez, Mike Perfit, and an anonymous reviewer are gratefully acknowledged.

\section{REFERENCES}

Aggrey, K.E., Muenow, D.W., and Sinton, J.M., 1988. Volatile abundances in submarine glasses from the North Fiji and Lau back-arc basins. Geochim. Cosmochim. Acta, 52:2501-2506.

Anderson, A.T., 1974. Chlorine, sulfur, and water in magmas and oceans. Geol. Soc. Am. Bull., 85:1485-1492.

Carmichael, I.S.E., 1991. The redox states of basic and silicic magmas: a reflection of their source region? Contrib. Mineral. Petrol., 106:129-141.

* Abbreviations for names of organizations and publication titles in ODP reference lists follow the style given in Chemical Abstracts Service Source Index (published by American Chemical Society).
Carroll, M.R., and Rutherford, M.J., 1985. Sulfide and sulfate saturation in hydrous silicate melts. J. Geophys. Res., 90 (suppl.):C601-C612.

. 1987. The stability of igneous anhydrite: experimental results and implications for sulfur behavior in the $1982 \mathrm{El}$ Chichon trachyandesite and other evolved magmas. J. Petrol., 28:781-801.

- 1988. Sulfur speciation in hydrous experimental glasses of varying oxidation state: results from measured wavelength shifts of sulfur X-rays. Am. Mineral., 73:845-849.

Christie, D.M., Carmichael, I.S.E., and Langmuir, C.H., 1986. Oxidation states of mid-ocean ridge basalt glasses. Earth Planet. Sci. Lett., 79:397-411.

Connolly, J.W.D., and Haughton, D.R., 1972. The volume of sulfur in glass of basaltic composition formed under conditions of low oxidation potential. Am. Mineral., 57:1515-1517.

Czamanske, G.K., and Moore, J.G., 1977. Composition and phase chemistry of sulfide globules in basalt from the Mid-Atlantic Ridge rift valley near $37^{\circ} \mathrm{N}$ lat. Geol. Soc, Am. Bull., 88:587-599.

Davis, A.S., Clague, D.A., Schulz, M.S., and Hein, J.R., 1991. Low sulfur content in submarine lavas: an unreliable indicator of subaerial eruption. Geology, 19:750-753.

Devine, J.D., Sigurdsson, H., and Davis, A.N., 1984. Estimates of sulfur and chlorine yield to the atmosphere from volcanic eruptions and potential climatic effects. J. Geophys. Res., 89:6309-6325.

Dixon, J.E., Clague, D.A., and Stolper, E.M., 1991. Degassing history of water, sulfur, and carbon in submarine lavas from Kilauea volcano, Hawaii. $J$. Geol., 99:371-394.

Fryer, P., Taylor, B., Langmuir, C.H., and Hochstaedter, A.G., 1990. Petrology and geochemistry of lavas from the Sumisu and Torishima backarc rifts. Earth Planet. Sci. Lett., 100:161-178.

Fudali, R.F., 1965. Oxygen fugacities of basaltic and andesitic magmas. Geochim. Cosmochim. Acta, 29:1063-1075.

Garcia, M.O., Liu, N.W.K., and Muenow, D.W., 1979. Volatiles in submarine volcanic rocks from the Mariana island arc and trough. Geochim. Cosmochim. Acta, 43:305-312.

Gill, J.B., 1981. Orogenic Andesites and Plate Tectonics: New York (Springer-Verlag).

Hamlyn, P.R., and Keays, R.R., 1986. Sulfur saturation and second-stage melts: application to the Bushveld platinum metal deposits. Econ. Geol., 81:1431-1445.

Hamlyn, P.R., Keays, R.R., Cameron, W.E., Crawford, A.J., and Waldron, H.M., 1985. Precious metals in magnesian low-Ti lavas: implications for metallogenesis and sulfur saturation in primary magmas. Geochim. Cosmochim. Acta, 49:1797-1811.

Haughton, D.R., Roeder, P.L., and Skinner, B.J., 1974. Solubility of sulfur in mafic magmas. Econ. Geol., 69:451-467.

Hawkesworth, C.J., Hergt, J.M., Ellam, R.M., and McDermott, F., 1991. Element fluxes associated with subduction related magmatism. Philos. Trans. R. Soc. London A, 335:393-405.

Hawkins, J.W., Bloomer, S.H., Evans, C.A., and Melchior, J.T., 1984. Evolution of intra-oceanic arc-trench systems. Tectonophysics, 102:175-205.

Hawkins, J.W., Lonsdale, P.F., Macdougall, J.D., and Volpe, A.M., 1990. Petrology of the axial ridge of the Mariana Trough back arc spreading center. Earth Planet. Sci. Lett., 100:226-256.

Hawkins, J.W., and Melchior, J.T., 1985. Petrology of Mariana Trough and Lau Basin basalts. J. Geophys. Res., 90:11431-11468.

Hochstaedter, A.G., Gill, J.B., Kusakabe, M., Newman, S., Pringle, M., Taylor, B., and Fryer, P., 1990. Volcanism in the Sumisu rift. I. Major element, volatile and stable isotope geochemistry. Earth Planet. Sci. Lett., 100:179194.

Hochstaedter, A.G., Gill, J.B., and Morris, J.D., 1990. Volcanism in the Sumisu Rift. II. Subduction and non-subduction related components. Earth Planet. Sci. Lett., 100:195-209.

Huebner, J.S., and Sato, M., 1970. The oxygen fugacity-temperature relationships of manganese oxide and nickel oxide buffers. Am. Mineral., 55:934952.

Juster, T.C., Grove, T.L., and Perfit, M.R., 1989. Experimental constraints on the generation of FeTi basalts, andesites, and rhyodacites at the Galapagos Spreading Center, $85^{\circ} \mathrm{W}$ and $95^{\circ} \mathrm{W}$. J. Geophys. Res., 94:9251-9274.

Katsura, T., and Nagashima, S., 1974. Solubility of sulfur in some magmas at 1 atmosphere. Geochim. Cosmochim. Acta, 38:517-531.

Kilinc, A., Carmichael, I.S.E., Rivers, M.L., and Sack, R.O., 1983. The ferric-ferrous ratio of natural silicate liquids equilibrated in air. Contrib. Mineral. Petrol., 83:136-140. 
Kusakabe, M., Mayeda, S., and Nakamura, E., 1990. S, O and Sr isotope systematics of active vent materials from the Mariana backarc basin spreading axis at $18^{\circ} \mathrm{N}$. Earth Planet. Sci. Lett., 100:275-282.

MacLean, W.H., 1969. Liquidus phase relations in the FeS-FeO- $\mathrm{Fe}_{3} \mathrm{O}_{4}-\mathrm{SiO}_{2}$ systems and their application in geology. Econ. Geol., 64:865-884.

Mathez, E.A., 1976. Sulfur solubility and magmatic sulfides in submarine basalt glass. J. Geophys. Res., 81:4269-4276.

1980. Sulfide relations in Hole 418A flows and sulfur contents of glasses. In Donnelly, T., Francheteau, J., Bryan, W., Robinson, P., Flower, M., Salisbury, M., et al., Init. Repts. DSDP, 51, 52, 53 (Pt. 2): Washington (U.S. Govt. Printing Office), 1069-1085.

1984. Influence of degassing on oxidation states of basaltic magmas. Nature, 310:371-375.

Mathez, E.A., and Yeats, R.S., 1976. Magmatic sulfides in basalt glass from DSDP Hole 319A and Site 320, Nazca Plate. In Yeats, R.S., Hart, S.R., et al., Init. Repts. DSDP, 34: Washington (U.S. Govt. Printing Office), 363-373.

Mattioli, G.S., Baker, M.B., Rutter, M.J., and Stolper, E.M., 1989. Upper mantle oxygen fugacity and its relationship to metasomatism. J. Geol., 97:521-536.

McCullogh, M.T., and Gamble, J.A., 1991. Geochemical and geodynamical constraints on subduction zone magmatism. Earth Planet. Sci. Lett., $102: 358-374$.

Moore, J.G., and Fabbi, B.P., 1971. An estimate of the juvenile sulfur content of basalt. Contrib. Mineral. Petrol., 33:118-127.

Moore, J.G., and Schilling, J.-G., 1973. Vesicles, water, and sulfur in Reykjanes Ridge basalts. Contrib. Mineral. Petrol., 41:105-118.

Muenow, D.W., Liu, N.W.K., Garcia, M.O., and Saunders, A.D., 1980. Volatiles in submarine volcanic rocks from the spreading axis of the East Scotia Sea backarc basin. Earth Planet. Sci. Lett., 47:272-278.

Naldrett, A.J., Goodwin, A.M., Fisher, T.L., and Ridler, R.G., 1978. The sulfur content of Archean volcanic rocks and a comparison with ocean floor basalts. Can. J. Earth Sci., 15:715-728.

Natland, J.H., Meyer, P.S., Dick, H.J.B., and Bloomer, S.H., 1991. Magmatic oxides and sulfides in gabbroic rocks from Hole 735B and the later development of the liquid line of descent. In Von Herzen, R.P., Robinson, P.T., et al., Proc. ODP, Sci. Results, 118: College Station, TX (Ocean Drilling Program), 75-112.

Nilsson, K., 1993. Oxidation state, sulfur speciation, and sulfur concentration in basaltic magmas: examples from Hess Deep and the Lau Basin [Ph.D. dissert.]. Univ. of California, San Diego.

Nilsson, K., and Natland, J.H., 1991. Oxide crystallization and $f \mathrm{O}_{2}$ during differentiation of abyssal tholeiites and gabbros at Hess Deep, E. Pacific. Eos, 72:526.

Nilsson, K., and Peach, C., 1993. Sulfur speciation, oxidation state, and sulfur concentration in backarc magmas. Geochim. Cosmochim. Acta.

Parson, L., Hawkins, J., Allan, J., et al., 1992. Proc. ODP, Init. Repts., 135: College Station, TX (Ocean Drilling Program).
Perfit, M.R., and Fornari, D.J., 1983. Geochemical studies of abyssal lavas recovered by DSRV Alvin from eastern Galapagos Rift, Inca Transform, and Ecuador Rift. 2. Phase chemistry and crystallization history. J. Geophys. Res., 88:10530-10550.

Perfit, M.R., Gust, D.A., Bence, A.E., Arculus, R.J., and Taylor, S.R., 1980. Chemical characteristics of island-arc basalts: implications for mantle sources. Chem. Geol., 30:227-256.

Perfit, M.R., Langmuir, C.H., Balkisapa, M., Chappell, B., Johnson, R.W., Staudigel, H., and Taylor, S.R., 1987. Geochemistry and petrology of volcanic rocks from the Woodlark Basin: addressing questions of ridge subduction. In Taylor, B., and Exon, N.F. (Eds.), Marine Geology, Geophysics, and Geochemistry of the Woodlark Basin-Solomon Islands. Circum-Pac. Counc. Energy Miner. Resour., Earth Sci. Ser., 113-154.

Sack, R.O., Carmichael, I.S.E., Rivers, M.L., and Ghiorso, M.S., 1980. Ferric-ferrous equilibria in natural silicate liquids at $1 \mathrm{bar}$. Contrib. Mineral. Petrol., 75:369-376.

Sakai, H., Casadevall, T.J., and Moore, J.G., 1982. Chemistry and isotope ratios of sulfur in basalts and volcanic gases at Kilauea volcano, Hawaii. Geochim. Cosmochim. Acta, 46:729-738.

Sato, M., 1978. Oxygen fugacity of basaltic magmas and the role of gas forming elements. Geophys. Res. Lett., 5:447-449.

Sinton, J.M., and Fryer, P., 1987. Mariana Trough lavas from $18^{\circ} \mathrm{N}$ : implications for the origin of back arc basin basalts. J. Geophys. Res., 92:1278212802.

Tatsumi, Y., Hamilton, D.L., and Nesbitt, R.W., 1986. Chemical characteristics of fluid phases from a subducted lithosphere and origin of arc magmas: evidence from high pressure experiments and natural rocks. J. Volcanol. Geotherm. Res., 29:293-309.

Ueda, A., and Sakai, H., 1984. Sulfur isotope study of Quaternary volcanic rocks from the Japanese Islands Arc. Geochim. Cosmochim. Acta, 48:1837-1848.

Volpe, A.M., Macdougall, J.D., and Hawkins, J.W., 1987. Mariana Trough basalts (MTB): trace element and Sr-Nd isotopic evidence for mixing between MORB-like and arc-like melts. Earth Planet. Sci. Lett., 82:241-254. 1988. Lau basin (LBB): trace element and Sr-Nd isotopic evidence for heterogeneity in backarc basin mantle. Earth Planet. Sci. Lett., 90:174 186.

Wallace, P., and Carmichael, I.S.E., 1992. Sulfur in basaltic magmas. Geochim. Cosmochim. Acta, 56:1863-1874.

Wilson, A.D., 1960. The micro-determination of ferrous iron in silicate minerals by a volumetric and a colorimetric method. Analyst, 85:823-827.

Date of initial receipt: 1 March 1993

Date of acceptance: 29 June 1993

Ms 135SR-145 